\title{
Gender Based Violence Against Syrian Refugee Women in Turkey
}

\author{
Aysun Dogutas $^{ \pm}$
}

\begin{abstract}
Following the outbreak of war in Syria, many people had to move to neighbouring countries and beyond. Hence Turkey received a large number of Syrians as refugees since 2011. Syrian refugee women faced challenges arising from them being refugees and women. These experiences are not dissimilar to other refugee women's experiences around the world. This study aimed at analysing the news about Syrian refugee women in Turkish newspapers. Four well established Turkish newspapers with nationwide distribution (i.e. Habertürk, Cumhuriyet, Hürriyet and Internethaber) were screened between 2015 and 2019. It was found that Syrian women refugees faced gender-based violence in Turkey. Their experiences as concubines, and in prostitution as well as sexual assaults were mentioned in the news articles we have analysed.
\end{abstract}

Keywords: immigrant; Syria; women; Turkey; gender based violence.

\section{Introduction}

Migration is not a new phenomenon. People have been migrating within their own countries or internationally. Some literature argues that most of these migration flows are forced moves as a result of conflicts and insecurities (Sirkeci et al. 2019; Sirkeci, 2009). Forced migration means people who are forced to leave their home countries because of lack of protection provided by the authorities as a result of civil war, human rights violations, political oppression due to ethnic, religious identities and/or political opinions (Martin, 2002; Çalhan, 2008).

By the end of 2016, continuing conflicts, threats of persecution, violence and human rights violations have led to the displacement of an estimated 65.6 million people globally, of whom 22.5 million are refugees (UNHCR, 2016). This reached to 70.8 million by $2019^{1}$ and the main countries of origin of refugees in 2019 were Syria, followed by Afghanistan, and South Sudan. The uprising in Syria in March 2011 made 6,7 million people refugees fleeing home. After the uprising in Syria, many people had to move to nearby countries in search of safe and security. Turkey has been one of these countries. According to the report published on 31 July 2019 by the Ministry of Interior, there are 3,643,870 registered Syrian refugees in Turkey (UNHCR, 2019).

Female refugees' number is almost the same with male refugees. Most of these women had to migrate alone or with their kids. Women are travelling alone because they are single, or because they have lost their husbands during the war. In some cases, families become separated, either by smugglers or officials. Previous research has pointed to the difficulties and obstacles that may prevent women from migrating, including lack of economic resources, responsibility for children and children's welfare, restrictions on women travelling alone both within their own country and outside it, and fears of violence during migration (Freedman \& Jamal, 2009). These obstacles mean

\footnotetext{
${ }^{ \pm}$Dr Aysun Dogutas, Pamukkale University, Denizli, Turkey. E-mail: adogutas@pau.edu.tr.

${ }^{1}$ See https://www.unhcr.org/uk/figures-at-a-glance.html [Accessed: 10.10.2019]
} 


\section{Gender Based Violence Against Syrian Refugee Women in Turkey}

that often women do not migrate until they have absolutely no other choice (Freedman, 2015). It is for sure that "people only decide to move when they see that given conflict as a threat, an environment of insecurity, which is unmanageable" (Yazgan et al., 2015: 182; Sirkeci, 2009). Since the number of refugee Syrian women are too many, we can conclude that female migrants are risking the journey and have no choice other than migration. Even though these women move from their own locations, there are many obstacles that they will face throughout their migration journey. Lack of adequate accommodation facilities for refugees creates situations of insecurity for women (Freedman, 2016).

The difference between female and male refugees appears before they fled from their own country. Due to traditional practices, socio-cultural acceptances and social gender-based discrimination, Syrian women escape from their own country. They hoped to be saved from violence and pressure depended on gender violence, sexual abuse (Buz, 2006). However, they also faced problems and fear in Turkey. Syrian refugee women faced challenges due to being both refugee and women as other refugee women live other parts of the world. BMMYK sorted some problems Syrian refugee women and girls faced in shelter country, before and during escaping from their own country:

1- Physical and sexual assault and abuse,

2- Abandon and abuse of husband,

3- Gun battle and forcing to include to the army,

4- Sexual exploitation and forced prostitution,

5- Pack rape and impregnation,

6- Sexual assault by border officer or gangs during crossing border,

7- Contraction danger by human traffickers and slave traders,

8- Sexual assault as punishment after turnabout,

9- Sexual bullying to regulate legal statue,

10- Unrecognizing as a person,

11- Exclusion from the decision making process,

12- Preclusion to access to resources (BMMYK, 2017)

Sexual violence (SV) is experienced by many women living in conflict and post-conflict settings, during transit, and within destination countries (Parker, 2015; Keygnaert \& Guieu, 2015). A recent systematic review estimated that $21 \%$ of women in conflict countries had experienced sexual violence either by a stranger or an intimate partner (Hossain, Zimmerman \& Watts, 2014). Another study carried out in Belgium and the Netherlands, which interviewed 223 refugees in 2012, showed that $69.3 \%$ of refugee women experienced sexual violence since their arrival in the European Union (Keygneart, Vettenburg \& Temmerman, 2012). Similar to other countries, whether fieldworks related to social harmony and conflict or the news in the press in Turkey point out that problems lived by Syrian refugee women are at more different extent than lived by men and this difference of social gender as an inequality category had been doubled. It can be said that beside negative life circumstances created by migration, women's falling into multidimensional inequality spiral with the social gender factor. 
Other problems common among refugee women come up as early marriages, second wives and prostitution. These incidences appearing in the media were also on the records of police. It has been determined that early marriage was seen as a protection for refugee women and guarantees these women's lives through relatives. In other words, some Syrian women may have preferred marriage to overcome hardships in life. When foreign brides were examined according to their nationality, Syrian brides are the largest group comprising \%19,4 of the total in Turkey (TUIK, 2018). However, Syrian brides either prefer or force to be the second wife who is called co-wife illegally according to Turkish Civil Law beyond these statistics. In fact, the co-wife issue has been passed to a trade dimension. Women brought from Syria have been introduced and married to Turkish men by brokers and almost these Syrian co-wives have been employed as a helper (KARAR, 2015; Kivilcim, 2016; Özmenek Çarmıkl1, 2015). Unlike men, women had to overcome with threats of prostitution and sexual assault along with being co-wife.

News in the media show that some Syrian women fall into the trap of prostitution by being sold in casinos and camps of refugees (Cumhuriyet, 2015; T24, 2015), and at the same camps they were also exposed to rape (Agos, 2014). In general, Syrian refugees had appeared on the news pretty frequently in Turkey. These news mostly were about terrorism, security problems and crime, where Syrians are often accused by ungratefulness, portrayed as the source of economic problems, in an "we-they" contrast, they are described as a health risk. Syrian women were subjected to dual discrimination (AS-U-LİS, 2017). Doğanay and Çoban Keneş (2016) examined news stories and columns in three national newspapers and found that in these stories, Syrian asylum seekers were portrayed as a "threat". Another study also supports this by stating that "the representations of Syrian asylum seekers portray these individuals mostly as "poor" people "in need of help" as well as "threats" for social security (Pandır et al., 2015). Opposite to these studies, Çağlar and Özkır (2014) stated that some newspapers who are close to the government use positive expressions about Syrian refugees. However, they added that these positive expressions were constituted within their negative situations such as "will not go back to their countries" and "compulsory visit".

According to the report of Hrant Dink Foundation, news about Syrian refugees shared the common characteristics along the thematic lines below:

- Systematically mentioned in relation to murders, burglaries and assault incidents,

- Presented along with security problems and terrorism,

- Showed as responsible of unemployment and negative economic outlook,

- Tagged as a source of "tension" and disorder in general and as a threat to Turkey's demographic structure,

- Especially Syrian refugee women were presented as a threat to family and society (Medyada Kadının Yeri, 2017).

As it was seen at reports, field works and news, Syrian refugees especially women had been faced to many problems. To overcome these problems, sometimes they prefer and sometimes they forced to marry with too old Turkish men, be co-wives and also do prostitute. The Syrian refugees' mass migration to the border provinces in particular resulted in an increased number of child brides and instances of polygamy (Kirişçi, 2014). It has been stated in Aksu Kargın (2018)'s study that, as a result of financial hardships, some Syrian refugee families have forced their daughters to marry elderly Turkish men in return for dowry money or some other financial return (p.32). "The illegal 


\section{Gender Based Violence Against Syrian Refugee Women in Turkey}

marriages, however, do not involve only Syrian girls; they also involve middle-aged Syrian women who are single, widowed, or divorced. As is the case of the Syrian girls, the majority of these Syrian women enter into marriages with Turkish men -unmarried men as well as those who are already married - in order to escape financial hardships or to protect their honour" (Aksu Kargin, 2018, p.33). Syrian refugee women had no other chance for protection of themselves and their kids, food, place to live and survival. There is substantial number of researches done on sexual and genderbased violence toward refugee women around the world and in Turkey. In the following parts, firstly studies around the world and later studies in Turkey will be presented.

\section{Current studies on Syrian refugee women}

The experience of Syrian refugee women in Lebanon, facing institutionalised multi-systemic violence, is often lost in a reductionist analysis of women in war and gender-based violence (GBV) (Yasmine \& Moughalian, 2016). Masterson and et al.'s study showed that "Syrian refugee women are disproportionately affected by the situation in Lebanon, due to the increase in GBV (particularly intimate partner violence (IPV), early marriage, transactional sex, sexual assaults), as well as lack of access to emergency obstetric care, limited access to contraception (2014). Additionally, according to the Nobel Women's Initiative's 2016 report "There is presently $100 \%$ impunity for sexual crimes and other forms of gender-based crimes committed against refugee women (p. 9)" and "Women, refugees report a very high incidence of robbery, and the lack of money is making them very vulnerable to further exploitation, including sexual trafficking as they travel the refugee route through Europe" ( p. 9).

In 2008, 829 refugees were registered by the UNHCR in Morocco, of whom 251 were women and girls (Freedman \& Jamal, 2009). Many women remain unaware of the fact that they may be able to claim refugee status, for others, there are barriers to doing so, such as the fact of being unwilling to talk about persecutions they have suffered. In addition, it seems that the formal recognition of refugee status by the UNHCR in Morocco offers little real protection against the many forms of violence that migrants face, including the threat of arrest and deportation by Moroccan authorities. A representative of the Organisation Pan Africaine de lutte contrele Sida (OPALS) based in Morocco highlighted the way in which extreme sexual violence was used against migrant women in this way and recounted that many of the women accompanied by his association had been traumatised by such incidences of violence. Some of the women had been attacked by gangs, stripped naked in public and searched to see if they were hiding money in their vaginas before being raped (Freedman, 2012).

Another organisation called Amnesty International "organization interviewed 40 refugee women and girls in northern Europe last month who travelled from Turkey to Greece and then across the Balkans. All the women described feeling threatened and unsafe during the journey. Many reported that in almost all of the countries they passed through they experienced physical abuse and financial exploitation, being groped or pressured to have sex by smugglers, security staff or other refugees". The organisation also added "A dozen of the women interviewed said that they had been touched, stroked or leered at in European transit camps. One 22-year-old Iraqi woman told Amnesty International that when she was in Germany a uniformed security guard offered to give her some clothes in exchange for "spending time alone" with him" (2016).

In Turkey, studies on problems faced by Syrian refugee women are very scarce. Especially, studies on gender-based violence problem are limited. Of course there are studies on general problems of Syrian refugees, problems of children; however, there isn't much study on women refugees. One of these limited studies is Barın's (2014) study. According to Barın's (2014) study 
Syrian refugee women mostly complain about lack of designated authority to apply when they encountered any kind of problem or faced with violence or sexual assault. After detailed interviews with Syrian refugee women, it was observed that mostly women kept silent on violence and sexual assault incidents and due to this domestic violence cannot be observed (37). Claims on Syrian women's illegal marriages turned into a trader ship were taken place into reports as concerning refugee problems (Kirişçi, 2014, 37).Aksu Kargın (2018)'s research revealed that, in addition to unfortunate consequences in the labor market, the housing market, and healthcare services, the Syrian refugees' arrival to Turkey caused serious social problems especially in the border provinces. Child brides and religious marriages have been central to these problems.

Some of the studies done on refugee problems were done by NGO's such as Mazlumder, Mülteciler Derneği, and etc. and some governmental organizations like AFAD (Disaster and Emergency Management Presidency). According to these organizations' research reports knowledge of most of the Syrian refugee women were married with men outside the camps and they forced to return to camps was obtained. Also, early pregnancy and age disparity between husband and wife is surplus within the camps were observed (AFAD,2014). Even though early marriage is a custom within Syrian culture, early marriage among Syrian teenager girls' rate was increased significantly (Mazlumder, 2014).

\section{Aims of the Study}

Since the uprising in Syria in March 2011, over 4.3 million Syrians have fled to neighboring countries. In addition to being exposed to war and conflict, they are currently also deprived of the most basic needs, such as food, water, housing, education, healthcare, and protection (European Commission, 2015). Governmental institutions, and healthcare systems, as well as women's own interpersonal circles, are rarely addressed as underlying culprits negatively impacting Syrian women's sexual and reproductive health (SRH) (Guruge \& Khanlou, 2004). Thus, these women should survive. To be able to manage this, they encounter many obstacles. These obstacles can be very harmful sometimes. It goes up to being murdered.

This article attempts to document the various forms of sexual and gender-based violence (SGBV) experienced by refugee women by examining the newspapers published in Turkey. Newspapers are a rich source for analysing the perceptions of the public and how these perceptions are reflected according to the political divisions within the country (Göktuna Yaylacı \& Karakuş, 2015). Refugee women's protection from discrimination, inequality and abuse is a very essential issue. However, it is observed that these issues were not taken into consideration and policies intended to women are not fully developed (Dartnall \& Loots, 2009).

\section{Methods and Materials}

This study assumes that Syrian women are subjected to discrimination based on both nationality and sex. In order to see how this discrimination and sexual and gender based violence were reflected in the media, Syrian refugee women's representations on national newspapers are analysed in this study. This study was aimed to analyze news about Syrian refugee women at Turkish media.

Sample of the study was four different Turkish national newspapers ( Habertürk, Cumhuriyet, Hürriyet and Internethaber) starting from 2015 till 2019. To get a wide spread point of view these four newspapers were chosen. The reason for choosing four newspapers is to get different news from different point of views. Cumhuriyet is left-oriented, Hürriyet is right-oriented and Habertürk and İnternethaber are objective papers. After third newspaper the news started to be same, that's why 4 newspapers were chosen. As Rubin and Rubin (1995) stated if the data started to repeat stop collecting data. Thus, at the end of the third newspaper the researcher decided to stop collecting new data. 


\section{Gender Based Violence Against Syrian Refugee Women in Turkey}

Keyword used for searching news was "Syrian women refugees". After the detailed search, the researcher reached 54 different news. Repeated and unrelated news have been eliminated. Only the news related to the keywords were included.

After the data collection completed, the content analysis was carried out. The aim of content analysis is to explain how a group or event was represented through text or visual features (Leeuwen and Jewitt, 2001). While doing this, some questions related to contents' objective features were asked such as which themes were discussed about Syrian refugee women within the news (e.g. violence, burglary, murder, success, happiness, etc.) and how often these news were repeated? With this aim, the news were divided into categories, and the meanings to be derived from these repeated categories were identified. Firstly the key categories were determined as violence, sexual assault, and marriage. Categories and contents of the news were matched. These categories were determined by the ones frequently encountered in the literature review (Mollard, 2001, 6) and during the analysis. After the categories determined, coding table was created (Table 1). The frequency of appearance of categories within the texts was presented in the coding table. To eliminate and reduce the possible inconsistencies in coding, some techniques were used. First, all categories and codes were described transparently. Also, the encoders checked each other's coding and finally the principal investigator checked the coding to ensure a systematic coding.

Table 1. Categories and Codes used in Content Analysis

\begin{tabular}{llll}
\hline $\begin{array}{l}\text { Table 1 } \\
\text { Codes }\end{array}$ & & & \\
\hline Categories & Violence & Sexual Assault & Marriage \\
& & & \\
\hline Codes & Torture & Rape & Co-wife \\
& Seizure & Prostitution & Early-marriage \\
& Murder & & \\
& Suicide & & \\
\hline
\end{tabular}

\section{Findings}

Seven key themes emerged related to Syrian refugee women in the news collated from the selected outlets. These themes were torture, seizure, sexual assault, co-wife, prostitution, suicide, and murder. (Table 2).

Table 2. Frequency of codes

\begin{tabular}{cccccccc}
\hline Torture & Seizure & Sexual Assault & Co-wife & Prostitution & Suicide & Murder & Other \\
\hline 1 & 1 & 13 & 8 & 16 & 3 & 11 & 1 \\
\hline
\end{tabular}

After the analysis of four news outlets, 54 different news items were collected. Repeated and irrelevant news items were eliminated. According to the results, the most common news was about prostitution. These news mostly mentioned how Syrian women were forced to prostitution. The tone was more or less as follows: Since they don't have a place to live, with lack of money and being unprotected, Syrian refugee women should have accepted prostitution or they were forced to. In a news article from Hürriyet newspaper, it was said that "Şanlıurfa'da 1 saatte 50 Suriyeli konsomatris yakalandı (In an hour, 50 Syrian night club hostesses got caught in Şanlıurfa) (28.01.2016). Another news article said that "Suriyeli kadından içler acısı fuhuş itirafı! (Heartbreaking prostitution confession from a Syrian woman!) (İnternethaber, 09.08.2015). In detail of these news, it was mentioned that "Ayşe Vakkaf, age 31 and had 5 children was arrested who were accused of prostitution and also prostituting her sister". 
Second most repeated news was about sexual assaults. It had appeared 13 times. Elderly or young, married or not, pregnant or not, all Syrian women are often portrayed as prone to sexual assault according to these news. One of the news articles was titled "Imam camide Suriyeli kadınla basıldı (Imam was busted with a Syrian woman in mosque)" (Cumhuriyet, 21. 9. 2018). Another news heading was as "Suriyeli kadina cinsel istismarda bulunan sanığa 17.5 yıl hapis (17.5 years imprisonment for the man who sexually assaulted a Syrian woman)". In the detail of this article, it said after the trial the Syrian woman said "please don't let him go because he will kill me". At the court she also said that she was put to sleep by someone and brought to Turkey: "When I opened my eyes I was at A. Ç's home. I tried to escape from there five times but every time he caught me and beat me. He raped me three times within five days. I attempted suicide with a knife. I don't want to be in Turkey, I want to go to Syria to be with my children".

Murder was another frequently appeared theme in the news in Turkish media. 11 murder news were published. The reasons of these murders were unknown but the offenders were mostly husbands of these women. Two of them were murdered by their children, four by husbands, one was an honor killing while the offenders of the rest were unknown.

Being co-wife had appeared eight times in the news. According to these articles, it was portrayed that Syrian women should accept being a co-wife for survival because mostly they would become a helper not a wife. In one of these articles, the title was "Tragedy of Syrian Women: Sole remedy is marriage". It was said "In a foundation housing [dormitory/refuge] in Fatih, İstanbul, 11 women and 29 orphan children were sheltered. A worker at the foundation, Hudut Ahmet said that "A man who is 60 years old was applied to the foundation and wanted to marry with a 20 years old woman" (Cumhuriyet, 17.9. 2018). Another news article was about the price of Syrian women as a co-wife. Heading was "Utanç verici iddia! Suriyeli kadının fiyatı 5 bin TL! (Shameful Claim! The price of Syrian women is 5 thousand TL!). A further article on the same issue appeared claiming the price of Syrian women is 5 thousand TL, and 372 thousand women are as "co-wife" in Turkey (Internethaber, 08-04-2015).

Lastly, four news articles were about suicide, one was about torture, one was about seizure and one was about a Syrian woman who said that "to be able to avoid sexual assault, I mostly behave like a man".

\section{Discussion and Concluding Remarks}

Internal conflict in Syria starting from the spring of 2011, reflected as an intense migration flow to Turkey due to both geographical and political reasons. This flow had an effect on society and on media. While migration and asylum news were taken place fewer before, nowadays news about refugee people have been taken place much on Turkish media. It is normal that "Syrians have become the largest immigrant group in Turkey and it is very likely that they will be the centre of attention in migration debates for the foreseeable future" (Sirkeci, 2017, 133).

Of course these news were not positive. Most of these news were negative and often insulting or demeaning for refugees. Refugees were stuck on for the second time. Syrian people had a shock with the war in their country and they had to leave their country with their families or alone. They had many obstacles before and during migration. In addition to these obstacles, they had to face many other problems after migration in Turkey. Syrian women were all in this journey and their problems were doubled because of gender. Many Syrian women had to leave their homes without husband and family. Some of them were alone and some were with their kids. They had to survive at new places. They have faced many risks such as rape, sexual assault, murder, health, accommodation and etc. This is simply showing the dynamic nature of migration in search of security or avoiding insecurity at home, in transit and in destinations as proposed by Sirkeci (2009).

The problems faced by Syrian refugee women have been reflected in Turkish media as the current study showed. In this study, I aimed to establish what kind of news were made by Turkish newspapers about Syrian refugee women. News about Syrian refugee women appeared in four national news outlets in Turkey were analysed. 54 relevant news articles were identified. According to these articles, news were thematically categorised as prostitution (16), sexual assault (13), murder (11), co-wife (8), suicide (3), torture (1), seizure (1) and other (1). 


\section{Gender Based Violence Against Syrian Refugee Women in Turkey}

It is true that some Syrian refugee women have faced gender based violence in Turkey. The results of the current study are similar to those earlier studies. For example, Robbers and Morgan (2017) carried out a systematic literature review of articles published between 2000 and 2016 following the PRISMA guidelines. According to their review, "sexual violence against refugee women is a complex public health concern requiring a comprehensive, multi-component and culturally sensitive solution" (p. 79). The present study also found similar patterns as 16 prostitution and 13 sexual assault news had appeared in the review. These people are refugees but also women. Therefore, they are subjected to gender based violence such as prostitution, sexual assault and being co-wife beyond being refugees.

Following the prostition, sexual assault has the second highest rate and it also shows that these women need protection. Some of them faced sexual assault by armed men during the movement while some others experienced it sometimes after they settled in Turkey. A study by Freedman (2016) also provided similar evidence and stated that "women interviewed in Kos, for example, explained that they had been victims of violence at the hands of the Turkish police and coastguards as they crossed the country and attempted to leave for Greece. Additionally, an MSF psychologist told that one woman she met who had been detained by Turkish police and imprisoned for 45 days, during which time she had been separated from her husband and subjected to severe sexual violence" (p.22).

Being a co-wife is the most common sexual assault seen in Turkey. Many old men or the ones who wanted to marry for the second time are in the queue to get marry with a young Syrian refugee woman. Since these men think that Syrian women had to get marry to survive they take the opportunity. Mostly, these women taken as co-wives were forced to take on responsibilities and burdens for which they are not prepared; this, combined with the other potential problems associated with marriage, can result in depression and suicide (Özcebe \& Küçük Biçer, 2013). This explains the frequent news about suicide among Syrian immigrant women. Since these women were used as hostesses at night clubs, co-wives or seen as a sexual object, some of them consider committing suicide. Although, we found only 8 news articles about co-wives, there are many marriages in which Syrian refugee women became co-wives. Since second marriage is illegal in Turkey, these marriages are not official and only some of these marriages are reported. On the other hand, among Turkish natives everybody knows that co-wives are more wide spread than what is shown in the news. Some of these women either accept being used as a sexual objects or will be murdered. It is a very tragic situation that Syrian refugee women saw their families destroyed, then they had to flee their homes and families to survive in a new country, but, there, they face gender-based violence.

In Turkey, a country of (human) (in)security, millions of Syrians and other refugees arrived and remained, perhaps many were hoping eventually to be resettled somewhere more stable and democratic [than their countries of origin] (Sirkeci, 2017). This hope felt real as the Turkish government welcomed refugees, opened the borders and set camps and shelters. However, the government's responsibility should not end with bringing them to Turkey but continues in ensuring their welfare covering all areas of housing, employment and safety and security. Only then, Turkey's foreign policy objective which is to be an emerging regional and global power shaped its response to the refugee flow without securitisation, economisation and internationalisation (Gökalp Aras \& Sahin Mencutek, 2015) can be realised.

This study's findings showed that some of the Syrian refugee women faced gender based problems. However, to improve our understanding and knowledge about the problems Syrian refugee women face in Turkey, further qualitative studies are needed. The limitation of the current study is obvious that based on a limited number of news articles a snapshot has been produced. This should be interpreted with caution and bearing in mind that the volume and severity of the problems are likely to be much bigger than what these news articles used in this study may have conveyed. 


\section{References}

AFAD (2014). Suriye'den Türkiye'ye Nüfus Hareketleri, Kardeş Topraklarındaki Misafirlik, https://www.afad.gov.tr/Dokuman/TR/79-20140529153928-suriye'den-turkiye'ye-nufus-hareketleri,kardestopraklarindaki-misafirlik,-2014.pdf, 30/08/2014.

Agos (2014). "Suriyeli Mülteci Kadına Kapmta Tecavüz". Retrieved from http://www.agos.com.tr/tr /yazi/7939/suriyeli-multeci-kadina-kampta-tecavuz.

Aksu Kargın, İ. (2018). "War hits the women: Marriage as Syrian women's coping mechanism and its impact on Turkish women". Turkish Studies, 13(7): 31-45.

Amnesty International (2016). "Female refugees face physical assault, exploitation and sexual harassment on their journey through Europe". Retrieved from https://www.amnesty.org/en/latest/news/2016/01/female-refugeesface-physical-assault-exploitation-and-sexual-harassment-on-their-journey-through-europe/ on 19 February 2019.

AS-U-LİS (2017). "Suriyeli Mülteciler Medyada Nasıl Hedef Gösteriliyor". Retrieved from https:/hrantdink.org/tr/asulis/faaliyetler/projeler/medyadanefret-soylemi/934-medyada-suriyeli-multecilereyonelik-nefret-soylemivideosu-yayinlandi. (2017. 11.30).

Barın, H. (2015). “Türkiye'deki Suriyeli Kadınların Toplumsal Bağlamda Yaşadıkları Sorunlar ve Çözüm Önerileri”. Göç Araştirmalari Dergisi, 1(2): 10-56.

BMMYK (2017, October). "Fact Sheet: Turkey. UNHRC Türkiye”. Retrieved from http://www.unhcr.org/tr/ wpcontent/uploads/sites/14/2017/11/UNHCRTurkeyFactSheetOctober2017.pdf.

Buz, S. (2006). “Kadın ve Göç İlişkisi: Siğınan ve Sığınmacı Kadınlar Örneği”’. Unpublished Doctoral Dissertation, Hacettepe University, Ankara.

Cumhuriyet (2015). "Kamplarda Kadin Ticareti”. Retrieved from http://www.cumhuriyet.com.tr/ haber/turkiye/188373/Kamplardaki_kadin_ticareti.html.

Çağlar, İ. and Özkır, Y. (2014). "Suriyeli Mültecilerin Türkiye Basınında Temsili”, Ortadoğu Yıllı̆gl, 2014: 485501.

Çalhan, M. (2008). “National and Religious Identities of Children of Iranian Asylum-Seekers in Kayseri”. 2008. Yayınlanmamış Yüksek Lisans Tezi. Ortadoğu Teknik Üniversitesi Sosyal Bilimler Enstitüsü, Ankara.

Dartnall, L. \& Loots, L. (2009). “Forum Conference Report 2009”, Johennasburg.

Doğanay, Ü. and Çoban Keneş, H. (2016). "Yazılı basında Suriyeli 'mülteciler': Ayrımcı söylemlerin rasyonel ve duygusal gerekçelerinin inşası”, Mülkiye Dergisi, 40(1): 143-184

European Commission (2015). "Humanitarian aid and civil protection". Retrieved from http://ec.europa.eu/echo/files/aid/countries/factsheets/syria_en.pdf.

Freedman, J. (2016). "Sexual and gender-based violence against refugee women: a hidden aspect of the refugee "crisis". Reprod Health Matters, 24(47): 18-26. doi: 10.1016/j.rhm.2016.05.003.

Freedman, J. (2015). "Gendering the International Asylum and Refugee Debate”. Basingstoke: Palgrave Macmillan.

Freedman, J. (2012). “Analyzing the Gendered Insecurities of Migration”, International Feminist Journal of Politics, 14(1): 36-55, DOI:10.1080/14616742.2011.631281.

Freedman, J. and Jamal, B. (2009). "Violence against migrant women in the Euro-Med Region”. Copenhagen: Euromed Human Rights Network.

Gianna, M., Leila, R., Alison, M. (2017). "Programme potential for the prevention of and response to sexual violence among female refugees: a literature review", Reproductive Health Matters, 25(51): 69-89. DOI: 10.1080/09688080.2017.1401893.

Gökalp Aras, N. E. and Sahin Mencutek, Z. (2015). “The international migration and foreign policy nexus: the case of Syrian refugee crisis and Turkey". Migration Letters, 12(3): 193 - 208.

Göker, G. and Keskin, S. (2015). "Haber Medyası ve Mülteciler: Suriyeli Mültecilerin Türk Yazılı Basınındaki Temsili”. İletişim Kuram ve Araştırma Dergisi, 41: 229-256.

Göktuna Yaylacı, F. and Karakuş, M. (2015). "Perceptions and newspaper coverage of Syrian refugees in Turkey”. Migration Letters, 12(3): 238 - 250.

Guruge, Sepali - Khanlou, Nazilla. "Intersectionalities of influence: researching the health of refugee and refugee women". CJNR, 36/3, 2004: 32-47.

Hossain, M., Zimmerman, C., Watts, C. (2014). "Preventing violence against women and girls in conflict". Lancet, 383(9934): 2021-2022. 


\section{Gender Based Violence Against Syrian Refugee Women in Turkey}

KARAR (2015). "Suriyeli Kadınlarin Kuma Dramı". Retrieved from http://www.karar.com/gundemhaberleri/suriyeli-kadinlarin-kuma-drami\#.

Keygnaert, I. and Guieu, A. (2015). "What the eye does not see: a critical interpretive synthesis of European Union policies addressing sexual violence in vulnerable migrants". Reprod Health Matters, 23(46): 45-55.

Keygnaert, I., Vettenburg, N., Temmerman, M. (2012). "Hidden violence is silent rape: sexual and gender-based violence in refugees, asylum seekers and undocumented migrants in Belgium and the Netherlands". Cult Health Sex, 14(5): 505-520.

Kıvılcım, Z. (2016). "Legal Violence Against Syrian Female Refugees in Turkey". Feminist Legal Studies, 4(2): 193-214.

Kirişçi, K. (2014). “Misafirliğin Ötesine Geçerken Türkiye’nin “Suriyeli Sığınmacılar” Sınavı”. USAK \& Brookings, Ankara.

Martin, Philip L. "Germany Managing Migration in the 21st Century". Working Paper CIIP-1. 2002: 2-35

Masterson, Amelia Reese - Usta, Jinan - Gupta, Jumhka - Ettinger, Adrienne S. "Assessment of reproductive health and violence against women among displaced Syrians in Lebanon". BMC Women's Health, 2014, 14/25.

MAZLUMDER. "Kamp Dışında Yaşayan Suriyeli Kadın Sığınmacılar Raporu”. (2014).

"Medyada Kadınin Yeri”. Hrant Dink Vakfi: Retrieved from https://hrantdink.org/tr/asulis/faaliyetler/projeler/668medyada-kadin-inyerini-kadin-gazetecilerle-konusuyoruz-soylesisi. (11.30.2017).

Mollard, C. (2001). "Asylum: The truth behind the headlines". Oxfam. Norton. Retrieved from http://policypractice.oxfam.org.uk/publications/asylum-the-truth-behind-the-headlines-11959.

Mülteciler Derneği (2018). "Türkiye'deki Suriyeli Saylsı". Retrieved from http://multeciler.org.tr/turkiyedekisuriyeli-sayisi/ on 05.03.2018.

Nobel Women Initiative (2016). "Women Refugees at Risk in Europe". Retrieved from https://nobelwomensinitiative.org/wp-content/uploads/2016/03/Opening-Borders-Report_FINAL_WEB-1.pdf on 19 February 2019.

Özcebe, H. and Küçük Biçer, B. (2013). “Önemli bir kız çocuk ve kadın sorunu: Çocuk evlilikler. Türk Pediatri Arşivi, 48(2): 86-93. http://dergipark.ulakbim.gov.tr/tpedar/article/view/5000001777.

Özmenek Çarmıklı, E. (2015). "Misafirperverliğin Sınırları: Yeni Sorunların Başlangıcı”. TUSİAD Görüş Dergisi, 88: 22-25.

Pandır, M., Efe, İ. and Paksoy, A.F. (2015). "Türk basınında Suriyeli sığınmacı temsili üzerine bir içerik analizi”, Marmara İletişim Dergisi, 24: 1-26.

Parker, S. (2015). "Hidden crisis: violence against Syrian female refugees". Lancet. 385: 2341-2342.

Rubin, H. J. and Rubin, I.S. (1995). "Qualitative Interviewing: The Art of Hearing Data”. 2nd Edition. London: Sage Publications.

Sirkeci, I. (2009). Transnational mobility and conflict. Migration Letters, 6(1), 3-14.

Sirkeci, I. (2017). "Turkey's refugees, Syrians and refugees from Turkey: a country of insecurity". Migration Letters, 14/(1): 127-144.

Şahin, C. (2001). "Yurt Dışı Göçün Bireyin Psikolojik Sağlığı Üzerindeki Etkisine İlişkin Kuramsal Bir İnceleme”. Gazi Üniversitesi Gazi Eğitim Fakültesi Dergisi, 21(2).

Theo, V. L. and Carey, J. (ed.) (2001). Handbook of Visual Analysis. London: Sage.

TUIK (2018). "Evlenme ve Boşanma Istatistikleri". Retrieved from file://C:/Users/tu\%C4\%9Fba/Downloads/ Evlenme_ve_Bo\%C5\%9Fanma_\%C4\%B0statistikl_02.03.2018.pdf

United Nations High Commissioner for Refugees (2015). "Global trends forced displacement in 2015". Geneva: United Nations High Commissioner for Refugees (UNHCR).

Yasmine, R. and Moughalian, C. (2016). "Systemic violence against Syrian refugee women and the myth of effective intrapersonal interventions", Reproductive Health Matters, 24(47): 27-35, DOI: 10.1016/j.rhm.2016.04.008.

Yazgan, P., Utku, D.E., Sirkeci, I. (2015). Syrian Crisis and Migration. Migration Letters, 12(3): 181-192.

\section{List of the News Analysed}

http://www.hurriyet.com.tr/gundem/kahvehanede-fuhus-iddiasi-ozel-bolum-acarak-40967005

https://www.haberturk.com/bursa-haberleri/62573059-suriyeli-kadin-elleri-plastik-kelepce-ile-baglanip-bogularakolduruldu 
http://www.hurriyet.com.tr/gundem/istanbulda-yakilmis-olarak-bulunan-cesedin-sirri-suriyeli-kadinlarlabulusturuyordu-40813124

http://www.hurriyet.com.tr/gundem/turkiyedeki-suriyeli-kadinlar-yuzde-70i-turkce-konusamiyor-40938738

http://www.hurriyet.com.tr/suriyeli-kadin-ticaretine-hayir-eylemi-25822406

http://www.hurriyet.com.tr/suriyeli-kadin-ticaretine-hayir-eylemi-25822406

http://www.hurriyet.com.tr/gundem/tecavuze-ugradi-olumle-tehdit-edince-ailesi-dusuk-yaptirdigi-bebegi-gomdu28351688

http://www.hurriyet.com.tr/adanada-suriyeli-kadina-fuhus-tuzagi-28449451

http://www.hurriyet.com.tr/gundem/sanliurfada-1-saatte-50-suriyeli-konsomatris-yakalandi-40023432

http://www.hurriyet.com.tr/gundem/siginmaci-kadinlara-fuhus-yaptiran-suriyeli-kadin-tutuklandi-40046446

http://www.hurriyet.com.tr/suriyeli-kadin-intihar-icin-firat-nehrine-atladi-37286962

http://www.hurriyet.com.tr/ankarada-4-cocuk-annesi-suriyeli-kadin-kocasi-tarafindan-olduruldu-37299659

http://www.hurriyet.com.tr/suriyeli-kadin-dustu-mu-yoksa-kocasi-mi-atti-40226691

https://www.haberturk.com/gundem/haber/1301259-sanliurfada-huzur-operasyonu-28i-suriyeli-42-gozalti

http://www.hurriyet.com.tr/gundem/suriyeli-kadina-cinsel-istismarda-bulunan-saniga-17-5-yil-hapis-40241020

http://www.hurriyet.com.tr/gundem/suriyeli-kadinlara-iyilik-yapiyoruz-diye-kendilerini-savunuyorlar-40318692

http://www.hurriyet.com.tr/cesedi-bulunan-suriyeli-kadin-tore-cinayetine-k-40342626

http://www.hurriyet.com.tr/sanliurfada-huzur-operasyonu-53-gozalti-40342901

http://www.hurriyet.com.tr/gundem/peceyi-ac-5-tl-vereyim-kavgasi-2-agir-yarali-40425066

http://www.hurriyet.com.tr/gundem/suriyeli-kadinlara-fuhus-yaptiran-ev-sahibi-tutuklandi-40498377

http://www.hurriyet.com.tr/video/sakaryadaki-vahsetin-kurbani-suriyeli-anne-ve-oglunu-10-bin-kisi-ugurladi-40514128

http://www.hurriyet.com.tr/alanyada-fuhus-operasyonu-21-gozalti-40825898

http://www.hurriyet.com.tr/gundem/sanliurfada-vahset-7-cocuk-annesi-uvey-oglu-tarafindan-dove-dove-oldurduldu-

40569059

http://www.hurriyet.com.tr/esini-fuhus-yapmaya-zorlayan-suriyeli-gozaltina-40896839

http://www.cumhuriyet.com.tr/haber/turkiye/1089432/imam_camide_Suriyeli_kadinla_basildi.html

http://www.cumhuriyet.com.tr/haber/turkiye/1087598/_inancli_bir_hoca_diye_evlendi_k_busu_yasadi.html

http://www.cumhuriyet.com.tr/haber/turkiye/1084938/Suriyeli_kadinlarin_drami_Tek_care_evlilik.html

http://www.cumhuriyet.com.tr/haber/turkiye/1044698/7_aylik_hamile_kadinin_olumunde_cinayet_suphesi.html

http://www.cumhuriyet.com.tr/haber/turkiye/1002523/Bursa_da_vahset_18_yasindaki_Dima_nin_cesedi_bulundugun

da_kucaginda_bebegi_vardi.html

http://www.cumhuriyet.com.tr/haber/turkiye/966383/_Tacize_maruz_kalmamak_icin_erkek_gibi_davranmaya_basladi

m_html

http://www.cumhuriyet.com.tr/haber/turkiye/934839/Yardim_skandali..._Suriyeli_kadinlar_insani_yardim_karsiligi_ci

nsel_iliskiye_zorlandi_html

http://www.cumhuriyet.com.tr/haber/dunya/820919/Times_Turkiye_deki_utanc_tarifesini_yazdi_Suriyeli_cocuklar_6 bin_TL_ye_kuma_yapiliyor.html

http://www.cumhuriyet.com.tr/haber/turkiye/813713/Mersin_de_vahset_iki_kadin_bogazlari_kesilerek_olduruldu.htm 1

http://www.cumhuriyet.com.tr/haber/turkiye/648381/Nefret_cinayeti_Suriyeli_trans_kadin_evinde_olduruldu.html http://www.cumhuriyet.com.tr/haber/turkiye/645104/Suriyeli_kadin_evinde_olu_bulundu.html

http://www.cumhuriyet.com.tr/haber/turkiye/513114/Yaslari_15_olan_Suriyeli_kucuk_cocuklar_2-

3_bin_lira_karsiliginda_satiliyor_html

http://www.cumhuriyet.com.tr/koseyazisi/494528/Suriyeli_kadinlarin_cilesi.html

http://www.cumhuriyet.com.tr/haber/turkiye/485995/Denizli_de_katalogla_Suriyeli_kadin_satildigi_iddiasi.html http://www.cumhuriyet.com.tr/haber/turkiye/473508/Esi_ihbar_etti..._Rejim_askerleri_tecavuz_etti_.html

http://www.cumhuriyet.com.tr/haber/turkiye/358823/Suriyeli_kadin_A Arkadasimin_evinde_tecavuze_ugradim.html

http://www.cumhuriyet.com.tr/haber/turkiye/226679/_En_cok_kadin_o_astsubaya_gider_html

http://www.cumhuriyet.com.tr/haber/turkiye/180957/_Olmemek_icin_ugrasiyoruz_html

https://www.internethaber.com/cocuklarinin-yaninda-taciz-edilmisti-ilk-kez-konustu-1835097h.htm

https://www.internethaber.com/ikinci-es-sitesi-faaliyette-suriyeli-kadinlarla-ilgili-skandal-ifadeler-1832905h.htm

https://www.internethaber.com/suriyeli-kadina-fuhus-yaptiririken-basildi-1561097h.htm

https://www.internethaber.com/suriyeli-kadindan-icler-acisi-fuhus-itirafi-806175h.htm

https://www.internethaber.com/polisim-deyip-kadina-tecavuz-etti-796543h.htm

https://www.internethaber.com/utanc-verici-iddia-suriyeli-kadinin-fiyati-5-bin-tl-779770h.htm

https://www.internethaber.com/suriyeli-kadina-tarlada-tecavuz-770195h.htm 


\section{Gender Based Violence Against Syrian Refugee Women in Turkey}

https://www.haberturk.com/gundem/haber/1306487-suriyeli-kadina-cinsel-istismarda-bulunan-sanigi-175-yil-hapis https://www.haberturk.com/gundem/haber/1245565-sanliurfada-suriyeli-kadin-intihar-icin-firat-nehrine-atladi https://www.haberturk.com/gundem/haber/1052188-hatayda-suriyeli-kadina-fuhus-yaptiranlar-yakalandi https://www.haberturk.com/evlenecek-parayi-bulamayinca-suriyeli-kadinlari-yaralayip-bileziklerini-caldi-1791363 https://www.haberturk.com/gundem/haber/1514379-kiliste-suriyeli-kadina-esinden-iskence 